\title{
Isolation and genetic characterization of Toxoplasma gondii from free-ranging and captive birds and mammals in Pernambuco state, Brazil
}

\author{
Isolamento e caracterização genética de Toxoplasma gondii de aves e mamíferos de vida livre e \\ cativeiro em Pernambuco
Marcio André Silva ${ }^{1,2,3}$; Hilda Fátima Jesus Pena ${ }^{4^{*}}$; Herbert Sousa Soares ${ }^{4}$; Juliana Aizawa ${ }^{4}$; Solange Oliveira ${ }^{4}$; Bruna Farias Alves ; Dênisson Silva Souza'; Renata Pimentel Bandeira Melo'; Solange Maria Gennari ${ }^{4}$; Rinaldo Aparecido Mota ${ }^{5}$; Jean Carlos Ramos Silva ${ }^{1,3}$

\author{
' Laboratório de Saúde Única, Epidemiologia e Geoprocessamento, Departamento de Medicina Veterinária, Universidade Federal \\ Rural de Pernambuco - UFRPE, Recife, PE, Brasil \\ ${ }^{2}$ Parque Estadual de Dois Irmãos, Recife, PE, Brasil \\ ${ }^{3}$ Instituto Brasileiro para Medicina da Conservação - Tríade, Recife, PE, Brasil \\ ${ }^{4}$ Laboratório de Doenças Parasitárias, Departamento de Medicina Veterinária Preventiva e Saúde Animal, Faculdade de Medicina \\ Veterinária e Zootecnia, Universidade de São Paulo - USP, São Paulo, SP, Brasil \\ ${ }^{5}$ Laboratório de Bacterioses dos Animais Domésticos, Departamento de Medicina Veterinária, Universidade Federal Rural de \\ Pernambuco - UFRPE, Recife, PE, Brasil
}

Received May 21, 2018

Accepted July 11, 2018

\begin{abstract}
Recent genetic population studies on Toxoplasma gondii in Brazil have shown large genetic variability. The objective of the present study was to isolate and genotypically characterize T. gondii from free-ranging and captive wild mammals and birds in Pernambuco state, Brazil. Fragments of heart, brain, skeletal muscle and diaphragm tissue from 71 birds and 34 mammals, which were either free-ranging or captive, were collected. Samples from 32 of these animals were subjected to bioassays in mice. Samples from the remaining 73 animals underwent biomolecular diagnosis, using PCR technique, targeting a repetitive DNA fragment of $529 \mathrm{bp}$ in $T$. gondii. A non-virulent isolate (TgButstBrPE1) was obtained from a free-ranging striated heron (Butorides striata) and, based on primary samples, seven animals were found to be positive. The primary samples and the isolate obtained were subjected to PCR-RFLP using the markers SAG1, 5'3'SAG2, alt.SAG2, SAG3, BTUB, GRA6, c22-8, c29-2, L358, PK1, Apico and CS3. ToxoDB-RFLP genotype \#13 from the striated heron isolate and Type BrIII genotype from a captive otter (Lontra longicaudis) (PS-TgLonloBrPE1) were obtained. The present study describes the first isolation and genotypic characterization of $T$. gondii in free-ranging striated heron, and the first genotypic characterization of T. gondii in a captive otter.
\end{abstract}

Keywords: Toxoplasmosis, genotyping, diversity, wildlife, northeastern Brazil.

\section{Resumo}

Recentes estudos genéticos nas populaçôes deste parasita no Brasil têm mostrado grande variabilidade genética. O objetivo do presente estudo foi isolar e caracterizar genotipicamente $T$. gondii de aves e mamíferos de vida livre e de cativeiro no estado de Pernambuco, Brazil. Fragmentos de tecido do coração, cérebro, músculo esquelético e diafragma de 71 aves e 34 mamíferos de vida livre ou cativeiro foram colhidos. Amostras de 32 destes animais foram submetidas a bioensaios em camundongos. As amostras dos 73 animais restantes foram submetidas a diagnóstico biomolecular usando a técnica de PCR, tendo como alvo o fragmento repetitivo de $529 \mathrm{pb}$ do DNA de T. gondii. Dentre os 32 bioensaios conduzidos, obteve-se um isolado náo-virulento (TgButstBrPE1) de um socozinho (Butorides striata) de vida livre, e dentre as amostras

\footnotetext{
*Corresponding author: Hilda Fátima Jesus Pena. Departamento de Medicina

Veterinária Preventiva e Saúde Animal, Universidade de São Paulo - USP,

Avenida Prof. Dr. Orlando Marques de Paiva, 87, Cidade Universitária,

CEP 05508-270, São Paulo, SP, Brasil. e-mail: hfpena@usp.br
} 
primárias, sete animais foram positivos. As amostras primárias e o isolado foram submetidos a PCR-RFLP usando os marcadores SAG1, 5'3'SAG2, alt.SAG2, SAG3, BTUB, GRA6, c22-8, c29-2, L358, PK1, Apico e CS3. Foram obtidos o genótipo ToxoDB-RFLP \#13 do isolado do socozinho e o genótipo Type BrIII de uma lontra (Lontra longicaudis) de cativeiro (PS-TgLonloBrPE1). O presente estudo descreve o primeiro isolamento e caracterizaçáo genotípica de $T$. gondii em socozinho de vida livre, e a primeira caracterização genotípica de T. gondii em lontra em cativeiro.

Palavras-chave: Toxoplasmose, genotipagem, diversidade, fauna selvagem, nordeste brasileiro.

\section{Introduction}

Infections by Toxoplasma gondii are cosmopolitan, affecting endothermal animals, including humans (DUBEY, 2010). In Brazil, studies have revealed seroprevalence of approximately $90 \%$ in humans, especially in the southern region of the country, and also that clinical illness is almost always associated with cases of immunosuppression (DUBEY, 2010). Recent studies regarding the population genetics of $T$. gondii worldwide have shown that, although reproduction is almost always asexual, the genetic variability of this infectious agent is much greater than previously expected (PENA et al., 2008; SHWAB et al., 2014). This variability may be related to clinical conditions, which can range from unapparent infections to cases of encephalitis. Some of these conditions can end up causing the death of the host, even among immunocompetent individuals, whether these are humans or animals (DEMAR et al., 2008; CARME et al., 2009; DUBEY, 2010; WENDTE et al., 2011). Studies have suggested that the existence of a wild cycle for $T$. gondii with sexual reproduction in wild felids, together with genetic changes due to clonal reproduction (asexual) in multiple species of wild animals, could be intrinsically related to the existence of greater genetic variability of the parasite in South America (CARME et al., 2009; KHAN et al., 2011; WENDTE et al., 2011).

Demar et al. (2008) and Carme et al. (2009) suggested that this phenomenon may occur in Brazil, especially in areas bordering countries such as Guyana, French Guiana and Suriname, because of the continuous nature of the Amazon rainforest. Different genotypes of $T$. gondii found in isolates from Brazilian wild fauna reinforce this hypothesis (PENA et al., 2011; CANOÓN-FRANCO et al., 2013; BARROS et al., 2014; VITALIANO et al., 2014). However, studies on the genetics of $T$. gondii among the wild fauna of northeastern Brazil are still scarce.

In the state of Pernambuco, Brazil, Pena et al. (2011) carried out isolation and molecular characterization of $T$. gondii from a young male red-handed howler monkey (Alouatta belzebul) and from an adult male jaguarundi (Puma yagouaroundi) at the zoo of Parque Estadual de Dois Irmãos, located in Recife, Pernambuco. In other municipalities of this state, seroepidemiological surveys of infection by $T$. gondii in wild animals kept in captivity were conducted among neotropical felids (RAMOS SILVA et al., 2001), wild birds (LEITE et al., 2007), capuchin monkeys (Sapajus spp.) (FERREIRA et al., 2015), and marine manatees (Trichechus manatus) (ATTADEMO et al., 2016). Investigations on anti-T. gondii antibodies in free-ranging wild animals were conducted among cattle egrets (Bubulcus ibis) in Fernando de Noronha (COSTA et al., 2012), and among rodents and marsupials in the Atlantic Rainforest (SIQUEIRA et al., 2013). These studies demonstrated that infection by this parasite among wild animals presents wide geographical distribution in Pernambuco, which demands research on isolation and genetic characterization of T. gondii.

Considering the wide array of wild species with positive results in serodiagnostic investigations on $T$. gondii infection and the relatively low number of published scientific papers on genetic characterization of this parasite from wild animals in northeastern Brazil, the objective of the present study was to isolate and characterize the genotypes of $T$. gondii strains in free-ranging and captive wild mammals and birds in the state of Pernambuco.

\section{Material and Methods}

Between March 2014 and September 2015, fragments of the brain, heart, skeletal muscle and diaphragm of 105 wild animals (71 birds and 34 mammals) were collected (Table 1). These specimens were either free-living $(n=59)$ or kept in captivity $(n=46)$ at the zoo and Conservation Unit of Parque Estadual de Dois Irmãos and from the Tangará wild animal screening center of Agência Estadual de Meio Ambiente de Pernambuco (CPRH). Sampling was performed according to convenience, after these animals had died due to different causes.

The samples thus collected were divided into two groups. Samples from thirty-two animals were used for bioassays in mice and those from 73 animals were used to make direct molecular diagnosis. For the bioassay, tissue samples (between 5 and $50 \mathrm{~g}$ depending on the size of the animal) were collected, pooled and processed in accordance with the technique described by Dubey (1998). Aliquots of $1.0 \mathrm{~mL}$ of the final homogenate were inoculated subcutaneously into each of three Swiss mice, which were kept under observation for 45 days regarding the appearance of clinical signs of toxoplasmosis. At the end of the 45-day period, blood was drawn from the surviving mice for serological evaluation through the Modified Agglutination Test (MAT, cut-off titre $\geq 25$ ) (DUBEY \& DESMONTS, 1987). The mice were then euthanized and tissue imprints of their lungs and brains were examined to search for tachyzoites or tissue cysts to confirm infection by $T$. gondii (DUBEY, 1998).

Tissue samples collected for direct molecular diagnosis were individually macerated into a $0.85 \%$ saline solution. An aliquot of $300 \mu \mathrm{L}$ of each homogenate was subjected to DNA extraction using a commercial kit (Qiagen ${ }^{\circledast}$ DNeasy Blood \& Tissue, Dusseldorf, Germany), following the recommendations of the manufacturer. Toxoplasma gondii DNA in the samples was screened through PCR using primers TOX4 (CGCTGCAGGGAGGAAGACGAAAGTTG) and TOX5 (CGCTGCAGACACAGTGCATCTGGATT), 
Table 1. Free-ranging and captive wild birds and mammals from Pernambuco state, Brazil, used for isolation or direct molecular diagnosis of Toxoplasma gondii. 2014-2015.

\begin{tabular}{|c|c|c|c|}
\hline Species & Popular name & N. of specimens & Origin \\
\hline \multicolumn{4}{|l|}{ Birds } \\
\hline Amazona aestiva & Blue-fronted amazon & 3 & captive \\
\hline Amazona farinosa & Southern mealy amazon & 1 & captive \\
\hline Anodorhynchus hyacinthinus & Hyacinth macaw & 4 & captive \\
\hline Ara ararauna & Blue-and-yellow macaw & 1 & captive \\
\hline Ara chloropterus & Red-and-green macaw & 2 & captive \\
\hline Aramides cajaneus & Gray-nekced wood-rail & 1 & free-ranging \\
\hline Eupsittula cactorum & Cactus parakeet & 1 & captive \\
\hline Aratinga jandaya & Jandaya parakeet & 2 & captive \\
\hline Ardea alba & Grat white egret & 2 & free-ranging \\
\hline Asio clamator & Striped owl & 2 & free-ranging \\
\hline Athene cunicularia & Burrowing owl & 2 & free-ranging \\
\hline Butorides striata & Green-backed heron & 2 & free-ranging \\
\hline Cacicus cela & Yellow-rumped cacique & 2 & captive \\
\hline Caracara plancus & Southern caracara & 2 & free-ranging \\
\hline Cochlearius cochlearius & Boat-billed heron & 1 & free-ranging \\
\hline Colaptes melanochloros & Green-barred woodpeacker & 1 & free-ranging \\
\hline Columbina talpacoti & Ruddy ground-dove & 1 & free-ranging \\
\hline Crax alector & Black curassow & 1 & captive \\
\hline Crax fasciolata & Bare-faced curassow & 1 & captive \\
\hline Crax globulosa & Wattled curassow & 1 & captive \\
\hline Falco peregrinus & Peregrine falcon & 1 & captive \\
\hline Falco sparverius & American kestrel & 1 & free-ranging \\
\hline Guaruba guarouba & Golden parakeet & 2 & captive \\
\hline Icterus jamacaii & Campo troupial & 1 & captive \\
\hline Nycticorax nycticorax & Black-crowned night-heron & 3 & free-ranging \\
\hline Ortalis guttata & Speckled chacalaca & 1 & captive \\
\hline Pionites leucogaster & Green-thighed parrot & 1 & captive \\
\hline Pitangus sulphuratus & Great kiskadee & 1 & free-ranging \\
\hline Porphyrio martinicus & Purple gallinule & 1 & captive \\
\hline Pteroglossus inscriptus & Lettered araçari & 1 & captive \\
\hline Puffinus puffinus & Manx shearwater & 2 & free-ranging \\
\hline Pulsatrix perspicillata & Spectacled owl & 4 & $\begin{array}{c}3 \text { free-ranging } \\
1 \text { captive }\end{array}$ \\
\hline Rhea americana & Greater rhea & 2 & captive \\
\hline Rupornis magnirostris & Roadside hawk & 11 & $\begin{array}{c}8 \text { free-ranging } \\
3 \text { captive }\end{array}$ \\
\hline Tyto furcata & Common barn-owl & 5 & $\begin{array}{l}4 \text { free-ranging } \\
1 \text { captive }\end{array}$ \\
\hline Vanellus chilensis & Southern lapwing & 1 & captive \\
\hline \multicolumn{4}{|l|}{ Mammals } \\
\hline Alouatta caraya & Black-and-gold howler monkey & 1 & captive \\
\hline Ateles paniscus & Guiana spider monkey & 1 & captive \\
\hline Bradypus variegatus & Brown-throated sloth & 6 & free-ranging \\
\hline Callithrix jacchus & Common marmoset & 4 & free-ranging \\
\hline Caluromys philander & Bare-tailed woolly opossum & 1 & free-ranging \\
\hline Didelphis albiventris & White-eared opossum & 1 & free-ranging \\
\hline Leopardus tigrinus & Northern tiger cat & 1 & captive \\
\hline Lontra longicaudis & Neotropical otter & 2 & captive \\
\hline Mazama gouazoubira & Gray brocket & 2 & captive \\
\hline Nasua nasua & South american coati & 1 & free-ranging \\
\hline Procyon concrivorus & Crab-eating raccoon & 2 & captive \\
\hline Rattus rattus & House rat & 9 & free-ranging \\
\hline Sapajus flavius & Blond capuchin monkey & 2 & captive \\
\hline Tamandua tetradactyla & Southern tamandua & 1 & free-ranging \\
\hline TOTAL & & 105 & \\
\hline
\end{tabular}


targeting a non-coding 529bp DNA fragment that is repeated 200-300 times in the T. gondii genome (HOMAN et al., 2000).

The DNA extracted from the positive samples was then subjected to genotyping through the PCR-RFLP technique using 11 markers: SAG1, 3'5'SAG2 + alt.SAG2, SAG3, BTUB, GRA6, c22-8, c29-2, L358, PK1, Apico (SU et al., 2010) and CS3 (PENA et al., 2008). Samples with complete RFLP genotyping were also analyzed using 15 microsatellite markers (MS): TUB2, W35, TgMA, B18, B17, M33, IV.1 and X1.1 (typing markers); and N60, N82, AA, N61 N83, M48 and M102 (fingerprinting markers), following the protocols of Ajzenberg et al. (2010), in order to increase genotyping precision. The results were analyzed using the software Genemapper ${ }^{\oplus} 4.1$ (Applied Biosystems).

The present study was conducted while respecting biosafety and animal welfare norms under authorizations from SISBIO (No. 37855-1; Instituto Chico Mendes de Conservação da Biodiversidade, ICMBio); the Ethics Committee for the Use of Animals (CEUA) of Universidade Federal Rural de Pernambuco (UFRPE) (No. 109/2014); the Bioethics Committee of the School of Veterinary Medicine and Animal Science of Universidade de São Paulo (FMVZ-USP) (No. 1921061113); Parque Estadual de Dois Irmãos (PEDI) (No. 216/2014); and Agência Estadual de Meio Ambiente de Pernambuco (CPRH) (No. 010675/2014).

\section{Results}

Among the 32 samples animals that were used for the bioassay in mice, $T$. gondii was isolated from a free-ranging striated heron (Butorides striata) (3.1\%) in the metropolitan region of Recife-PE.
This isolate was named TgButstBrPE1, and ToxoDB-RFLP genotype \#13 was identified in it. During the 45-day period of post-inoculation observation, none of the three mice inoculated in this group died or presented clinical signs of toxoplasmosis.

Among the 73 animals used for direct diagnosis by means of PCR, seven $(9.6 \%)$ were positive for $T$. gondii. Heart was the positive tissue in six of these animals. Type BrIII genotype (ToxoDB-RFLP genotype \#8) was diagnosed from a captive otter (Lontra longicaudis) at the zoo of Parque Estadual de Dois Irmãos (Table 2). This sample was identified as PS-TgLonloBrPE1. Table 3 lists the results from RFLP genotypic characterization of the T. gondii isolate from the free-ranging striated heron and from the primary sample of the captive otter.

The microsatellite analysis enabled genotyping of the isolate TgButstBrPE1, which presented the following sequence of alleles: TUB2 $=291, \mathrm{~W} 35=242, \mathrm{TgMA}=205, \mathrm{~B} 18=162, \mathrm{~B} 17=342$, $\mathrm{M} 33=165$, IV. $1=278$, XI. $1=356, \mathrm{~N} 60=142, \mathrm{~N} 82=109$, $\mathrm{AA}=277, \mathrm{~N} 61=87, \mathrm{~N} 83=312, \mathrm{M} 48=213$ and $\mathrm{M} 102=164$, which corresponds to Caribbean 1 type.

\section{Discussion}

Diagnoses of $T$. gondii infection obtained through isolation and molecular methods among wild birds in Brazil have been reported both from free-living wild specimens (GONDIM et al., 2010; LIMA et al., 2011; VILELA et al., 2011; BARROS et al., 2014; VITALIANO et al., 2014) and from captive specimens (VITALIANO et al., 2010). Nonetheless, research involving molecular diagnoses of $T$. gondii in northeastern Brazil is still

Table 2. Positive tissue samples for Toxoplasma gondii through direct PCR*, from free-ranging and captive wild birds and mammals in Pernambuco state, Brazil. 2014-2015.

\begin{tabular}{|c|c|c|c|c|c|c|}
\hline \multirow{2}{*}{ ID } & \multirow{2}{*}{ Species } & \multirow{2}{*}{ Popular name } & \multirow{2}{*}{ Origin } & \multicolumn{2}{|c|}{ Geographical location } & \multirow{2}{*}{ Positive tissue } \\
\hline & & & & Latitude & Longitude & \\
\hline 32 & Sapajus flavius & Blond capuchin & Captive & $08^{\circ} 00^{\prime} 20.79^{\prime \prime}$ & $34^{\circ} 56^{\prime} 51.85^{\prime \prime}$ & Diaphragm \\
\hline 54 & Pulsatrix perspicillata & Spectacled owl & Captive & $07059 ’ 9.28 ”$ & $34055^{\prime} 54.89^{\prime \prime}$ & $\begin{array}{l}\text { Brain } \\
\text { Heart }\end{array}$ \\
\hline 64 & Lontra longicaudis & Otter & Captive & $08^{\circ} 00^{\prime} 20.79^{\prime \prime}$ & $34^{\circ} 56^{\prime} 51.85^{\prime \prime}$ & Heart \\
\hline 96 & Sapajus flavius & Blond capuchin & Captive & $08^{\circ} 00^{\prime} 20.79^{\prime \prime}$ & $34^{\circ} 56^{\prime} 51.85^{\prime \prime}$ & Heart \\
\hline 98 & Falco sparverius & American kestrel & Free-ranging & $07^{\circ} 55^{\prime} 17.23 "$ & $34^{\circ} 55^{\prime} 44.39^{\prime \prime}$ & $\begin{array}{l}\text { Heart } \\
\text { Muscle }\end{array}$ \\
\hline 101 & Butorides striata & Striated heron & Free-ranging & $08^{\circ} 2^{\prime} 5.37^{\prime \prime}$ & $344^{\circ} 55^{\prime} 8.97^{\prime \prime}$ & $\begin{array}{l}\text { Heart } \\
\text { Brain } \\
\text { Muscle }\end{array}$ \\
\hline 105 & Lontra longicaudis & Otter & Captive & $08^{\circ} 00^{\prime} 20.79^{\prime \prime}$ & $34^{\circ} 56^{\prime} 51.85^{\prime \prime}$ & $\begin{array}{c}\text { Heart } \\
\text { Muscle }\end{array}$ \\
\hline
\end{tabular}

*529-bp fragment target (Homan et al., 2000). ID 105: T. gondii strain was named PS-TgLonloBrPE1.

Table 3. Multilocus genotyping of Toxoplasma gondii from the isolate TgButstBrPE1, from a free-ranging striated heron (Butorides striata), and from PS-TgLonloBrPE1, from a primary sample of a captive otter (Lontra longicaudis), obtained through PCR-RFLP. Pernambuco state, Brazil. 2014-2015.

\begin{tabular}{|c|c|c|c|c|c|c|c|c|c|c|c|c|c|}
\hline \multirow{2}{*}{ Sample ID } & \multicolumn{12}{|c|}{ PCR-RFLP markers } & \multirow{2}{*}{ RFLP genotype } \\
\hline & SAG1 & 5'3'SAG2 & SAG2 & SAG3 & BTUB & GRA6 & c22-8 & c29-2 & L358 & PK1 & APICO & CS3 & \\
\hline TgButstBrPE1 & I & I & I & I & I & III & II & III & III & I & III & III & $\# 13$ \\
\hline $\begin{array}{l}\text { PS-TgLonloBrPE1 } \\
\text { (ID\#105) }\end{array}$ & I & III & III & III & III & III & II & III & III & III & III & III & Type BrIII \\
\hline
\end{tabular}


scarce (GONDIM et al., 2010). In the case of wild mammals, isolation and molecular diagnosis seem to be more common, in relation to both captive and free-living specimens (SILVA et al., 2006; TRUPPEL et al., 2010; PENA et al., 2011; CABRAL et al., 2013; CAÑÓN-FRANCO et al., 2013; VITALIANO et al., 2014).

The ToxoDB-RFLP genotype \#13 that was identified in the present study had been previously described in isolates from chickens, goats, a red-handed howler monkey and a fox (Cerdocyon thous) in northeastern Brazil (DUBEY et al., 2008; FEITOSA et al., 2017; RAGOZO et al., 2010; PENA et al., 2011; ALMEIDA et al., 2017). These findings corroborate the wide circulation of this genotype in this region. The present study provides the first description of a T. gondii isolate genotyped as \#13 from a wild bird. This isolate caused no mortality in mice, thus corroborating other authors' findings that ToxoDB-RFLP genotype \#13 is associated with low virulence in mice (DUBEY et al., 2008; RAGOZO et al., 2010; PENA et al., 2011). Moreover, a microsatellite analysis (which presented greater resolution) revealed the same sequence of alleles (unpublished data), that were found in the isolate from a red-handed howler monkey, also from Recife, Pernambuco (PENA et al., 2011). This indicates that there is wide circulation of this clone in the city of Recife. The fact the striated heron examined here was rescued a few days before its death indicates that the infection was acquired in the wild. This suggests that the isolates from domesticated animals and from captive wild animals are genotypically similar to those isolated from free-ranging wild animals.

Regarding direct molecular diagnosis based on primary samples, Dubey (2010) reported that this technique was very effective for the diagnosis, but not so much for genotyping, due to the small amount of genetic material usually found. Molecular diagnosing of $T$. gondii using primary samples from wild animals has been described in capybaras (TRUPPEL et al., 2010), sparrows (VILELA et al., 2011), several species of small neotropical felids (CAÑÓN-FRANCO et al., 2013) and several species of wild birds and mammals (VITALIANO et al., 2014). Cañón-Franco et al. (2013) also conducted genotyping using primary samples, individually, obtaining $14.6 \%(63 / 433)$ of success, similar to what was obtained in the present study (14.3\%).

Two blond capuchins (Sapajus flavius), two otters (L. longicaudis), one spectacled owl (Pulsatrix perspicillata), one American kestrel (Falco sparverius) and one striated heron (B. striata) were positive for $T$. gondii using PCR. These are the first reports of molecular diagnosis using primary samples in those species. In the case of the blond capuchins, a critically endangered species, identification of this agent is important, since these specimens were part of a reproduction program for ex situ conservation (LYNCH ALFARO et al., 2014; FERREIRA et al., 2015; IUCN, 2018).

The otter in which the T. gondii Type BrIII genotype was identified did not present any clinical sign of toxoplasmosis. The death of this specimen was associated with senility and multiple organ failure due to neoplastic metastases. Type BrIII is a common clonal lineage circulating in Brazilian territory, and it is found in different animal hosts and also in humans.

The two striated herons that were positive for $T$. gondii in the present study were individuals from two different districts in Recife. They had been living near water courses in densely populated areas. The facts that this species inhabits urban areas and has a diet composed of fish and other aquatic organisms (GWYNNE et al., 2010) suggest that the transmission route was probably ingestion of $T$. gondii oocysts from water contaminated by domestic sewage. These results indicated that this species is an intermediate host and can serve as an indicator for $T$. gondii infection among the synanthropic wild fauna of Pernambuco.

\section{Conclusion}

The genotyping information obtained from the samples of wild animals of the present study corroborated the findings that ToxoDB-RFLP genotype \#13 has wide circulation in northeastern Brazil and that Type BrIII is a widely distributed clonal lineage in Brazil.

\section{Acknowledgements}

The authors are grateful to Fundação de Amparo à Ciência do Estado de Pernambuco (FACEPE), Agência Estadual de Meio Ambiente de Pernambuco (CPRH) and the Superintendency of Instituto Brasileiro do Meio Ambiente e Recursos Naurais Renováveis in Pernambuco (IBAMA-PE) for their financial support and for conceding licenses for the use of biological material from wild fauna. S.M.G., R.A.M. and J.C.R.S. received fellowships from Conselho Nacional de Desenvolvimento Científico e Tecnológico (CNPq).

\section{References}

Ajzenberg D, Collinet F, Mercier A, Vignoles P, Dardé ML. Genotyping of Toxoplasma gondii isolates with 15 microsatellite markers in a single multiplex PCR assay. J Clin Microbiol 2010; 48(12): 4641-4645. http:// dx.doi.org/10.1128/JCM.01152-10. PMid:20881166.

Almeida JC, Melo RPB, Morais Pedrosa C, Silva Santos M, Barros LD, Garcia JL, et al. First isolation and RFLP genotyping of Toxoplasma gondii from crab-eating fox (Cerdocyon thous-Linnaeus, 1766). Acta Trop 2017; 169: 26-29. http://dx.doi.org/10.1016/j.actatropica.2017.01.010. PMid:28119049.

Attademo FLN, Ribeiro VO, Soares HS, Luna FO, Sousa GP, Freire ACB, et al. Seroprevalence of Toxoplasma gondii in captive Antillean manatee (Trichechus manatus manatus) in Brazil. J Zoo Wildl Med 2016; 47(2): 423-426. http://dx.doi.org/10.1638/2015-0100.1. PMid:27468012.

Barros LD, Taroda A, Zulpo DL, Cunha IAL, Sammi AS, Cardim ST, et al. Genetic characterization of Toxoplasma gondii isolates from eared doves (Zenaida auriculata) in Brazil. Rev Bras Parasitol Vet 2014; 23(4): 443448. http://dx.doi.org/10.1590/S1984-29612014073. PMid:25517521.

Cabral AD, Gama AR, Sodré MM, Savani ESMM, Galvão-Dias MA, Jordão LR, et al. First isolation and genotyping of Toxoplasma gondii from bats (Mammalia: Chiroptera). Vet Parasitol 2013; 193(1-3): 100104. http://dx.doi.org/10.1016/j.vetpar.2012.11.015. PMid:23200751.

Cañón-Franco WA, Araújo FAP, López-Orozco N, Jardim MMA, Keid LB, Dalla-Rosa C, et al. Toxoplasma gondii in free-ranging wild small felids from Brazil: molecular detection and genotypic characterization. Vet Parasitol 2013; 197(3-4): 462-469. http://dx.doi.org/10.1016/j. vetpar.2013.07.019. PMid:23932730. 
Carme B, Demar M, Ajzenberg D, Dardé ML. Severe acquired toxoplasmosis caused by wild cycle of Toxoplasma gondii, French Guiana. Emerg Infect Dis 2009; 15(4): 656-658. http://dx.doi.org/10.3201/ eid1504.081306. PMid:19331765.

Costa DGC, Marvulo MFV, Silva JSA, Santana SC, Magalhães FJR, Lima CDF Fo, et al. Seroprevalence of Toxoplasma gondii in domestic and wild animals from the Fernando de Noronha, Brazil. J Parasitol 2012; 98(3): 679-680. http://dx.doi.org/10.1645/GE-2910.1. PMid:22150091.

Demar M, Ajzenberg D, Serrurier B, Dardé ML, Carme B. Atypical Toxoplasma gondii strain from a free-living jaguar (Panthera onca) in French Guiana. Am J Trop Med Hyg 2008; 78(2): 195-197. PMid:18256411.

Dubey JP, Desmonts G. Serological responses of equids fed Toxoplasma gondii oocysts. Equine Vet J 1987; 19(4): 337-339. http://dx.doi. org/10.1111/j.2042-3306.1987.tb01426.x. PMid:3622463.

Dubey JP, Velmurugan GV, Chockalingam A, Pena HF, Oliveira LN, Leifer CA, et al. Genetic diversity of Toxoplasma gondii isolates from chickens from Brazil. Vet Parasitol 2008; 157(3-4): 299-305. http:// dx.doi.org/10.1016/j.vetpar.2008.07.036. PMid:18804329.

Dubey JP. Advances in the life cycle of Toxoplasma gondii. Int J Parasitol 1998; 28(7): 1019-1024. http://dx.doi.org/10.1016/S00207519(98)00023-X. PMid:9724872.

Dubey JP. Toxoplasmosis of animals and humans. New York: CRC Press; 2010.

Feitosa TF, Ribeiro Vilela VL, Almeida-Neto JL, Santos A, Morais DF, Alves BF, et al. High genetic diversity in Toxoplasma gondii isolates from pigs at slaughterhouses in Paraíba state, northeastern Brazil: Circulation of new genotypes and Brazilian clonal lineages. Vet Parasitol 2017; 244: 76-80. http://dx.doi.org/10.1016/j.vetpar.2017.07.017. PMid:28917322.

Ferreira DRA, Ribeiro VO, Laroque PO, Wagner PGC, Pinheiro-Júnior JW, Silva JCR, et al. Risk factors associated with Toxoplasma gondii infection in captive Sapajus spp. Am J Primatol 2015; 77(5): 558-562. http://dx.doi.org/10.1002/ajp.22377. PMid:25676671.

Gondim LSQ, Abe-Sandes K, Uzêda RS, Silva MSA, Santos SL, Mota RA, et al. Toxoplasma gondii and Neospora caninum in sparrows (Passer domesticus) in the northeast of Brazil. Vet Parasitol 2010; 168(1-2): 121 124. http://dx.doi.org/10.1016/j.vetpar.2009.09.055. PMid:19879051.

Gwynne JA, Ridgely RS, Tudor G, Argel M. Aves do Brasil: pantanal e cerrado. São Paulo: Horizonte; 2010.

Homan WL, Vercammen M, De Braekeleer J, Verschueren H. Identification of a 200- to 300-fold repetitive 529 bp DNA fragment in Toxoplasma gondii, and its use for diagnostic and quantitative PCR. Int J Parasitol 2000; 30(1): 69-75. http://dx.doi.org/10.1016/S00207519(99)00170-8. PMid:10675747.

International Union for Conservation of Nature-IUCN. The IUCN red list of threatened species [online]. Cambridge: IUCN; 2018 [cited 2018 Jan 05]. Available from: http://www.iucnredlist.org/details/136253/0

Khan A, Dubey JP, Su C, Ajioka JW, Rosenthal BM, Sibley LD. Genetic analyses of atypical Toxoplasma gondii strains reveal a fourth clonal lineage in North America. Int J Parasitol 2011; 41(6): 645-655. http:// dx.doi.org/10.1016/j.ijpara.2011.01.005. PMid:21320505.

Leite AS, Alves LC, Faustino MAG. Serological survey of toxoplasmosis in birds from Cracidae family in a wild bird center facility at Pernambuco state, Northeast of Brazil. Med Vet (Recife) 2007; 1(1): 55-57.
Lima VY, Langoni H, Silva AV, Pezerico SB, Castro AP, Silva RC, et al. Chlamydophila psittaci and Toxoplasma gondii infection in pigeons (Columba livia) from São Paulo state, Brazil. Vet Parasitol 2011; 175(1-2): 9-14. http://dx.doi.org/10.1016/j.vetpar.2010.10.006. PMid:21055877.

Lynch Alfaro JW, Izar P, Ferreira RG. Capuchin monkey research priorities and urgent issues. Am J Primatol 2014; 76(8): 705-720. http://dx.doi.org/10.1002/ajp.22269. PMid:24668460.

Pena HFJ, Gennari SM, Dubey JP, Su C. Population structure and mouse-virulence of Toxoplasma gondii in Brazil. Int J Parasitol 2008, 38(5): 561-569. http://dx.doi.org/10.1016/j.ijpara.2007.09.004. PMid:17963770.

Pena HFJ, Marvulo MFV, Horta MC, Silva MA, Silva JCR, Siqueira $\mathrm{DB}$, et al. Isolation and genetic characterisation of Toxoplasma gondii from a red-handed howler monkey (Alouatta belzebul), a jaguarund (Puma yagouaroundi), and a black-eared opossum (Didelphis aurita) from Brazil. Vet Parasitol 2011; 175(3-4): 377-381. http://dx.doi. org/10.1016/j.vetpar.2010.10.015. PMid:21055880.

Ragozo AMA, Pena HFJ, Yai LEO, Su C, Gennari SM. Genetic diversity among Toxoplasma gondii isolates of small ruminants from Brazil: Novel genotypes revealed. Vet Parasitol 2010; 170(3-4): 307-312. http://dx.doi. org/10.1016/j.vetpar.2010.02.024. PMid:20236768.

Ramos Silva JC, Ogassawara S, Adania CH, Ferreira F, Gennari SM, Dubey JP, et al. Seroprevalence of Toxoplasma gondii in captive Neotropical felids from Brazil. Vet Parasitol 2001; 102(3): 217-224. http://dx.doi. org/10.1016/S0304-4017(01)00523-4. PMid:11777601.

Shwab EK, Zhu XQ, Majumdar D, Pena HFJ, Gennari SM, Dubey JP, et al. Geographical patterns of Toxoplasma gondii genetic diversity revealed by multilocus PCR-RFLP genotyping. Parasitology 2014; 141(4): 453-461. http://dx.doi.org/10.1017/S0031182013001844. PMid:24477076.

Silva AV, Moraes Gimenes Bosco S, Langoni H, Bagagli E. Study of Toxoplasma infection in Brazilian wild mammals: Serological evidence in Dasypus novemcicntus Linnaeus, 1758 and Euphractus sexcinctus Wagler, 1830. Vet Parasitol 2006; 135(1): 81-83. http://dx.doi.org/10.1016/j. vetpar.2005.08.013. PMid:16188389.

Siqueira DB, Aléssio FM, Mauffrey JF, Marvulo MFV, Ribeiro VO, Oliveira RL, et al. Seroprevalence of Toxoplasma gondii in wild marsupials and rodents from the Atlantic Forest of Pernambuco State, northeastern region, Brazil. J Parasitol 2013; 99(6): 1140-1143. http:// dx.doi.org/10.1645/GE-2855.1. PMid:23829204.

Su C, Shwab E, Zhou P, Zhu X, Dubey JP. Moving towards an integrated approach to molecular detection and identification of Toxoplasma gondii. Parasitology 2010; 137(1): 1-11. http://dx.doi.org/10.1017/ S0031182009991065. PMid:19765337.

Truppel JH, Reifur L, Montiani-Ferreira F, Lange RR, Castro Vilani RG, Gennari SM, et al. Toxoplasma gondii in capybara (Hydrochaeris hycrochaeris) antibodies and DNA detected by IFAT and PCR. Parasitol Res 2010; 107(1): 141-146. http://dx.doi.org/10.1007/s00436-0101848-4. PMid:20445992.

Vilela SMO, Silva JSA, Pinheiro JW Jr, Moraes EPBX, Saukas TN, Gondim LFP, et al. Sparrows (Passer domesticus L.) as intermediary hosts of Toxoplasma gondii in poultry farms from the "agreste" region of Pernambuco, Brazil. Pesq Vet Bras 2011; 31(2): 169-172. http:// dx.doi.org/10.1590/S0100-736X2011000200013.

Vitaliano SN, Mineo TWP, André MR, Machado RZ, Mineo JR, Werther K. Experimental infection of crested caracara (Caracara plancus) with 
Toxoplasma gondii simulating natural conditions. Vet Parasitol 2010; 172(1-2): 71-75. http://dx.doi.org/10.1016/j.vetpar.2010.04.010. PMid:20451327.

Vitaliano SN, Soares HS, Minervino AHH, Santos ALQ, Werther K, Marvulo MFV, et al. Genetic characterization of Toxoplasma gondii from Brazilian wildlife revealed abundant new genotypes. Int J Parasitol
Parasites Wildl 2014; 3(3): 276-283. http://dx.doi.org/10.1016/j. ijppaw.2014.09.003. PMid:25426424.

Wendte JM, Gibson AK, Grigg ME. Population genetics of Toxoplasma gondii: new perspectives from parasite genotypes in wildlife. Vet Parasitol 2011; 182(1): 96-111. http://dx.doi.org/10.1016/j.vetpar.2011.07.018. PMid:21824730. 